\title{
Using the UKCP09 probabilistic scenarios to model the amplified impact of climate change on drainage basin sediment yield
}

\author{
T. J. Coulthard ${ }^{1}$, J. Ramirez ${ }^{1}$, H. J. Fowler ${ }^{2}$, and V. Glenis ${ }^{2}$ \\ ${ }^{1}$ Department of Geography, University of Hull, Hull, UK \\ ${ }^{2}$ School of Civil Engineering and Geosciences, Cassie Building, Newcastle University, Newcastle, UK \\ Correspondence to: T. J. Coulthard (t.coulthard@hull.ac.uk)
}

Received: 4 July 2012 - Published in Hydrol. Earth Syst. Sci. Discuss.: 20 July 2012

Revised: 13 November 2012 - Accepted: 13 November 2012 - Published: 26 November 2012

\begin{abstract}
Precipitation intensities and the frequency of extreme events are projected to increase under climate change. These rainfall changes will lead to increases in the magnitude and frequency of flood events that will, in turn, affect patterns of erosion and deposition within river basins. These geomorphic changes to river systems may affect flood conveyance, infrastructure resilience, channel pattern, and habitat status as well as sediment, nutrient and carbon fluxes. Previous research modelling climatic influences on geomorphic changes has been limited by how climate variability and change are represented by downscaling from global or regional climate models. Furthermore, the non-linearity of the climatic, hydrological and geomorphic systems involved generate large uncertainties at each stage of the modelling process creating an uncertainty "cascade".

This study integrates state-of-the-art approaches from the climate change and geomorphic communities to address these issues in a probabilistic modelling study of the Swale catchment, UK. The UKCP09 weather generator is used to simulate hourly rainfall for the baseline and climate change scenarios up to 2099, and used to drive the CAESAR landscape evolution model to simulate geomorphic change. Results show that winter rainfall is projected to increase, with larger increases at the extremes. The impact of the increasing rainfall is amplified through the translation into catchment runoff and in turn sediment yield with a $100 \%$ increase in catchment mean sediment yield predicted between the baseline and the 2070-2099 High emissions scenario. Significant increases are shown between all climate change scenarios and baseline values. Analysis of extreme events also shows the amplification effect from rainfall to sediment delivery with even greater amplification associated with higher return
\end{abstract}

period events. Furthermore, for the 2070-2099 High emissions scenario, sediment discharges from 50 -yr return period events are predicted to be 5 times larger than baseline values.

\section{Introduction}

Anthropogenic climate changes are projected to considerably alter the hydrological cycle (Douville et al., 2002). For certain parts of the world this may lead to an increase in precipitation frequency and/or magnitude (Palmer and Ralsanen, 2002). In turn, this will lead to increases in the magnitude and frequency of flood events and the damage and hazards associated with flooding (Milly et al., 2002). Of particular concern are the $20 \%$ of the global population that live in river basins that will experience increased flooding through increased stream flow and/or rainfall as a result of climate change (Kleinen and Petschel-Held, 2007). The impact of these floods will be widespread and may include damage to urban and rural infrastructure located on floodplains (Dutta et al., 2003; Schreider et al., 2000; Tockner and Stanford, 2002). In the UK, evidence suggests that there will be increased occurrence of extreme rainfall events and flooding in the next century (Dankers and Feyen, 2008; Ekstrom et al., 2005; Fowler and Ekström, 2009; Pall et al., 2011; Prudhomme et al., 2003) and this may cause a 100-600\% monetary increase in riverine flood damages (Feyen et al., 2011).

Whilst flooding itself is an important hazard and has been widely researched in the literature, how changes in flood magnitude and frequency will affect patterns of erosion and deposition within river basins has received little attention. 
However, these geomorphic changes will have important impacts on

1. Channel incision and aggradation, which will alter channel capacity, flood conveyance and thus future flood risk.

2. Undermining of structures (e.g. bridges, flood defences) or siltation/deposition problems.

3. Channel pattern change, with shifts from stable meandering channels to more dynamic braided patterns.

4. Increased fine sediment concentrations in streams, which may affect water quality.

5. Habitat changes caused by erosion and deposition, especially fine sediment which affects salmonids, for example.

6. Increased movement of contaminants associated with sediments (e.g. heavy metals).

7. Fluxes of carbon associated with river sediments.

Therefore, predicting and understanding the changes in the levels of erosion and deposition in rivers that may result from climate change is essential in order to plan and manage for any adverse impacts. A variety of different approaches have tried to address the effect of historical climatic variability on channel geometry. For example, Lane et al. (2007) examined how recent changes in channel geometry, caused by changing flood frequencies and magnitudes, can affect subsequent levels of flood inundation. They found that natural changes in channel shape could have the equivalent impact on flooding as a $20 \%$ increase in flood magnitude caused by climate change. Over longer time scales others have made more qualitative assessments of the variability in levels of erosion and deposition in river channels by interpreting sedimentological records and matching them to historical climatic events (Gomez et al., 1995; Magilligan et al., 1998), thus using information on past behaviour to infer future changes. Although these methods have proven useful and major advances have been made in dating by collating large regional databases (Macklin et al., 2010), recent work has suggested that there are limitations to using the sedimentological record as an analogue for likely future climate change impacts as (a) climate events may not leave any evidence of geomorphic change (Jerolmack and Paola, 2010; Smith et al., 2010; Van De Wiel et al., 2007), and; (b) the climate may change in ways that have not been recorded historically. Therefore, given the difficulties found in using the palaeo-sedimentological record and the uncertainties in how future climate change may manifest itself, numerical models are useful tools with which to quantitatively explore the potential geomorphic responses to a changing climate.

Previous studies have used a range of numerical models operating at different time and space scales to explore the impacts of climate change on sediment response and channel change. These range from soil erosion models, to landscape evolution models, to channel based models. Firstly, soil erosion models typically focus on erosive hill slope processes and models such as the WEPP soil erosion model (Laflen et al., 1997) have been applied to hillslopes and fields to derive general trends in sediment response to long-term climate change (O'Neal et al., 2005; Pruski and Nearing, 2002). For example, using WEPP Favis-Mortlock and Guerra (1999) modelled soil erosion over a 48-ha hillslope field in the Amazon using projected daily precipitation from 2050 and estimated that average annual sediment yield will increase by $27 \%$. However, although hillslope scale models, like WEPP, are suitable for investigating seasonal scale responses to climate change, they are less suited for predicting responses to high intensity, short duration, rainfall events that occur at time scales much smaller (sub-hourly) than the daily time step at which the models operate (Merritt et al., 2003) and which may change disproportionately with climate change (Fowler et al., 2009). An alternative is catchment scale soil erosion models which have been applied using a high temporal resolution (sub-hourly, hourly) (Elliott et al., 2012; Nearing et al., 2005), but due to computational limits these are restricted to examining individual storms that span days. More synoptic catchment scale responses have been realised using models that sacrifice spatial heterogeneity (i.e. microtopography) for faster computation (Nunes and Nearing, 2011; Nunes et al., 2008). For example, the soil erosion model SWAT divides a catchment into sub-units with similar landscape characteristics and then routes sub-unit level runoff and sediment downstream to derive catchment scale quantities (Arnold et al., 1998). Chaplot (2007) applied SWAT on 2 catchments, 918 and $51 \mathrm{~km}^{2}$ in area, with semi-arid and humid climates. Future changes in climate were then represented by the amplification (10-40\%) of $100 \mathrm{yr}$ of synthetically produced daily rainfall generated from $9 \mathrm{yr}$ of observed rainfall.

Secondly, landscape evolution models (for recent reviews see Tucker and Hancock, 2010; Van De Wiel et al., 2011) typically simulate hillslope and channel processes with an emphasis on how the interaction between both leads to longerterm landscape development. Tucker and Slingerland (1997) used the GOLEM model to show how over long time scales (1000s of years) there was a lag in the sediment response of a drainage basin to stepped changes in climate drivers. Tucker and Bras (2000) also used GOLEM to examine the interaction of rainfall variability on arid and humid catchments, showing how poorly vegetated catchments were less sensitive to rainfall changes. In this model, however, climate was represented as a mean value that did not include shorter term events, and daily or even monthly changes. Temme and Veldkamp (2009) used the LAPSUS model to simulate $50000 \mathrm{yr}$ of development of the Okhombe Valley, SA, demonstrating how landscape response lags climate drivers. Further work by Temme et al. (2009) explored how future changes in 
climate may affect landscape change predicted by the LAPSUS model by projecting GCM predictions of future temperatures to $1000 \mathrm{yr}$ into the future. Importantly, this work made a direct connection between GCM projections and geomorphology. But the temporal resolution of the climate data was daily, thus ignoring smaller scale changes including extreme rainfall events. More recently, van Balen et al. (2010) simulated the impact of late Pleistocene climate changes on the Rhine-Meuse using the CHILD model. To represent climate change, they used daily resolution predictions of runoff to drive the model, though they simulated only the larger events.

There are few soil erosion/landscape evolution models that are able to use high resolution (e.g. hourly) rainfall data to generate runoff and simulate erosion and deposition at the short-time scales needed to explore the effect of extreme events. One of these models is the CAESAR model (see Van de Wiel et al., 2007) which has been used to simulate changes in sediment yield from river catchments over the Holocene (Coulthard and Macklin, 2001), during the last 500-1000 yr (Welsh et al., 2009) and for recent storm events in Australia (Hancock and Coulthard, 2011). Importantly, the CAESAR model is event based (driven by an hourly rainfall record) but in previous studies climate changes have been represented very simply by only increasing or decreasing the magnitude of the rainfall record.

Thirdly, channel based models focus solely on how erosion and deposition within channels affects sediment delivery. Channel and upstream sediment inputs are considered, but hillslopes are not explicitly modelled (and linked) as with landscape evolution models. Verhaar et al. (2010) modelled future changes in the Saint-Lawrence River, Quebec, using a one dimensional hydraulic model. Seven scenarios of future discharges under different climate change conditions were simulated and all led to increases in sediment delivery. Gomez et al. (2009) also used a one-dimensional hydraulic and sediment transport model linked to a climate-driven hydrological model to project climate change impacts on the sediment transport regime of the Waipaoa River, NZ. Their results were mixed, showing decreases in water discharges but slight increases in suspended sediment loads under climate change. Of most concern were their projections that bed aggradation could reduce channel conveyance and thus increase the likelihood of flooding (as per Lane et al., 2007).

With all previously published approaches there are considerable limitations in how climate variability and climate change are represented through downscaling from Global or Regional Climate Models (GCMs, RCMs). For a comprehensive review of downscaling methods used in hydrological modelling (see Fowler et al., 2007). Often the effect of climate change on rainfall is heavily simplified by using only mean or average climate values, which may be simply increased or decreased (e.g. Tucker and Slingerland, 1997). More sophisticated approaches have included increasing the overall magnitude of rainfall (e.g. Coulthard et al., 2000), commonly called the "perturbation method" or "delta change" approach (Prudhomme et al., 2002), or repeating data from years containing larger flood events (e.g. Hancock, 2009). The simplest approaches ignore the variability in rainfall events and even the more sophisticated methods used thus far greatly simplify the role of flood frequency, magnitude and extreme events on sediment delivery and channel response. Whilst these simplifications are perfectly justified given the scope and context of many of the reported modelling studies (e.g. when modelling millennial time scales), under climate change the changing risk of large flood events may have a profound effect on river systems and their geomorphology (Mayes et al., 2006; Milan, 2012) and thus a more sophisticated downscaling approach that accounts for changes to both the variability and extremes of rainfall is needed.

Another issue hampering the development of models of geomorphic change under climate change is the non-linearity of the systems involved which produce large uncertainties at each stage of the modelling chain: the uncertainty "cascade" (Schneider, 1983). Here we use a modelling cascade from GCMs, feeding into RCMs, which drive weather generators (or other downscaling methods) to simulate rainfall, which is then fed into hydrological models to generate runoff, which in turn can be used to simulate river hydraulics and finally sediment transport leading to erosion and deposition. Uncertainties result from grid resolution, process parameterization, model structure and emissions scenario in GCMs (e.g. Giorgi and Francisco, 2000; Covey et al., 2003) and when using RCM data the sources of uncertainty increase, as outputs are influenced by RCM resolution, numerical scheme, physical parameterizations and the forcing lateral boundary conditions (Rummukainen et al., 2001; Déqué et al., 2007; Elía et al., 2008). Downscaling methods, such as weather generators, produce another layer of uncertainty (Fowler et al., 2007). Catchment hydrology also produces non-linear responses, with the timing and size of runoff being dependent on the timing and magnitude of the driving rainfall, as well as the antecedent conditions and, for example, nonlinear changes in soil moisture stores and infiltration. Sediment transport, driven by runoff is notoriously non-linear and hard to predict (Cudden and Hoey, 2003; Gomez and Church, 1989) and the integration of sediment transport across a catchment through erosion, deposition and re-working creates another non-linearity/uncertainty. For example, recent work (Coulthard et al., 2005; Coulthard and Van De Wiel, 2007; Van De Wiel and Coulthard, 2010) describes how identically sized flood events can generate bed load discharges that vary over several orders of magnitude. They summarise that a large flood is required to move a large amount of sediment, but a large flood does not necessarily mean a large amount of sediment will be moved.

Ensembles of model runs are commonly used to address this issue of modelling uncertainty: using a probabilistic approach first demonstrated in publications such as Fowler et al. (2007) and Fowler and Ekström (2009) to produce 
probability density functions (pdfs) of changes in impacts. This approach is now central to most climate change impact assessments in the UK as it has been adopted by the UK Climate Projections (UKCP09; Murphy et al., 2009). Essentially, this approach uses multiple model runs at every step of the uncertainty cascade to try to quantify the uncertainty in the impact response. However, this approach has yet to be fully endorsed by geomorphic modellers, possibly due to their long model run times and the added complexity of sediment transport. As a result, to date there are few, if any, geomorphic simulations using a probabilistic rather than deterministic framework even though the largest uncertainties may be associated with the most extreme events (Schwierz et al., 2010), those that cause the largest changes geomorphologically.

This study takes state-of-the-art approaches from the climate change impacts and geomorphological communities and brings these together to address these issues in a modelling study of the Swale catchment, UK. GCM and RCM uncertainties are addressed by using the UKCP09 weather generator to simulate hourly rainfall for the baseline climate, 1961-1990, and under a range of climate change scenarios up to 2099. These data are then used as inputs to the computationally efficient CAESAR landscape evolution model to simulate catchment wide erosion and deposition. By running several thousand simulations through the modelling uncertainty cascade this will, for the first time, provide us with meaningful simulations of how a river system may geomorphically respond to projected changes in climate.

\section{The UKCP09 weather generator}

UKCP09 provide probabilistic projections of precipitation, temperature and other variables for the UK using perturbed physics ensemble (PPE) simulations from a single climate model, each employing a different parameterization within expert-specified bounds (Murphy et al., 2004; Stainforth et al., 2005). The PPE is derived from the slab-ocean model configuration of the HadCM3 GCM, HadSM3, and a smaller ensemble of simulations from the coupled atmosphericoceanic model (HadCM3). However, PPEs do not account for the uncertainties introduced by different climate model structures; this is estimated by using the PPE to predict the results of 12 additional global climate models. Downscaled projections at a resolution of $25 \mathrm{~km}$ are then obtained from a further ensemble of $11 \mathrm{RCM}$ variants configured from HadCM3 as described in Murphy et al. (2009). However, the spatial resolution is still too coarse to use as a direct input to hydrological models. Therefore, an additional downscaling method, the UKCP09 Weather Generator (Jones et al., 2009), is provided with the UKCP09 Climate Projections (Murphy et al., 2009) to generate local scale scenarios $(5 \mathrm{~km})$.

The UKCP09 Weather Generator was developed from the EARWIG model described by Kilsby et al. (2007).
This incorporates a stochastic rainfall model based on the Neyman-Scott Rectangular Pulses (NSRP) model (Cowpertwait, 1991; Burton et al., 2008) and a weather generator model based on regression relationships between daily weather variables and daily rainfall (and their autocorrelative properties, see Kilsby et al., 2007 for details). The UKCP09 weather generator is able to generate synthetic hourly climate data for any $5 \mathrm{~km}$ grid cell or small catchment in the UK, for a baseline climate (1961-1990) and future climate scenarios. In the case of a small catchment (defined as up to $405 \mathrm{~km}$ grid cells), statistics for each individual $5 \mathrm{~km}$ grid cell are averaged and the weather generator is then fitted as a point model to this "averaged" set of statistics.

The weather generator produces future scenarios by applying monthly change factors $(\mathrm{CFs})$ to observed statistics derived for each $5 \mathrm{~km}$ grid cell across the UK. For the UKCP09 WG, 10000 monthly CFs have been derived from the UKCP09 probabilistic projections (Murphy et al., 2009) to define the range of possible climate change futures for each $5 \mathrm{~km}$ grid box within the UK. This method makes the implicit assumption that any bias in the control scenario of the climate model is the same for the future scenario - therefore, although the absolute values from the climate model may be biased, we assume the projections of change are valid. Since CFs are derived from the RCM, all $5 \mathrm{~km}$ grid cells within the same $25 \mathrm{~km}$ by $25 \mathrm{~km}$ RCM grid box will have the same set of CFs. Five multiplicative $\mathrm{CFs}$ are used to change future rainfall statistics of mean daily rainfall, proportion dry days, variance of daily rainfall, skewness of daily rainfall and lag-1 autocorrelation. Additive/multiplicative factors are derived for change in temperature mean/variance; other weather variables are dependent on rainfall and temperature and these relationships are assumed to remain constant under climate change. The calculation and application of the CFs is described by Kilsby et al. (2007) and Jones et al. (2009). Observed monthly statistics for each $5 \mathrm{~km}$ grid box are perturbed using the CFs to derive a set of future monthly climate statistics. In the case of a small catchment, the CFs from the $25 \mathrm{~km}$ grid cell nearest to the centroid of the selected area are used. The weather generator is then refitted using these perturbed statistics to generate a set of future simulations.

The UKCP09 Climate Projections provide an ensemble of 10000 sets of CFs. To run all 10000 would be too computationally intensive for this study, particularly since we are interested in the effect of different time slices and emission scenarios on the results; therefore, a significant challenge is the use of an appropriate means of sampling this dataset to preserve the range of probabilistic information. Burton et al. (2010) take a 1000 member random sample of UKCP09 projections which is then sub-sampled to identify 12 weighted samples for subsequent application in a high resolution urban flood model. Christierson et al. (2012) use latin hypercube sampling to obtain 20 samples for use with hydrological models to assess changes in river flows at the UK 
national scale within the context of water resource planning. Alternatively, UKCP09 guidance recommends that a minimum of 100 random samples of the 10000 sets of change factors are required to maintain the representativeness of the sampled dataset.

\section{The CAESAR model}

The CAESAR landscape evolution model (Coulthard et al., 2000, 2002, 2005; Coulthard and Van De Wiel, 2007; Van De Wiel et al., 2007) simulates landscape development by routing water over a regular grid of cells and altering elevations according to erosion and deposition from fluvial and slope processes. CAESAR can be run in two modes: a catchment mode (as used here), with no external in-fluxes other than rainfall; and a reach mode, with one or more points where sediment and water enter the system. For both modes the model requires the specification of several parameters or initial conditions including elevation, grain sizes and rainfall (catchment mode) or a flow input (reach mode). In theory, CAESAR model operation is simple, where rainfall falling on topography drives fluvial and hillslope processes that determine the spatial distribution of erosion and deposition for a given time step. This alters the topography, which becomes the starting point for the next time step. Outputs of the model are elevation and sediment distributions through space and time, and discharges and sediment fluxes at the outlet(s) through time. There are four main components to CAESAR, a hydrological model, the flow model, fluvial erosion and deposition and slope processes.

When running in catchment mode, CAESAR uses a rainfall input to generate runoff over the catchment. This is calculated using an adaptation of TOPMODEL (Beven and Kirkby, 1979) that contains a lumped soil moisture store which, when exceeding a threshold value, creates surface runoff. The surface runoff generated by the hydrological model is then routed using a flow model.

Flow is the main driver for the geomorphological processes in alluvial environments and CAESAR uses a "flowsweeping" algorithm, which calculates a steady-state, uniform flow approximation to the flow field. Discharge is distributed to all cells within a 2-5 cell range in front of a cell according to the differences in water elevation of the donor cell and bed elevations in the receiving cell. If no eligible receiving cells can be identified in the sweep direction, i.e. if there is a topographic obstruction, then the discharge remains in the donor cells to be distributed in subsequent sweeps (in different directions) during the same scan. Flow depths and flow velocity are calculated from discharges using Manning's equation.

These flow depths and velocities are then used to model the transport and deposition of sediments. CAESAR distinguishes between sediment of nine fractions, which are transported either as bed load or as suspended load, depending on the grain sizes. CAESAR provides two different methods of calculating sediment transport, based on the Einstein (1950) and the Wilcock and Crowe (2003) equations. The Einstein (1950) approach was developed based on (predominantly) sand based laboratory channels, whereas the Wilcock and Crowe (2003) formula was based on field and lab data from a coarser bed gravel/sand mix. For this application - which is largely sand based - we have chosen to use the Einstein (1950) method. A calculation of shear stress is required to drive the Einstein formulation and this is calculated from flow velocity.

Deposition of sediments differs between bed load and suspended load. For each iteration all transported bed load material is deposited in the receiving cells where it can be reentrained in the next iteration. Deposition of suspended sediments, however, is derived from fall velocities and concentrations for each suspended sediment fraction.

Incorporating multiple grain sizes, selective erosion, transport and deposition of the different size fractions will result in spatially variable sediment size distributions. Since this variability is expressed not only horizontally, but also vertically, it requires a method of storing sub-surface sediment data. This is carried out by using a system of layers comprising an active layer representing the stream bed; multiple buried layers (strata); a base layer; and, if required, an immovable bedrock layer. The layers have a fixed thickness and their position is fixed relative to the bedrock layer. Up to 20 strata can be stored at any cell on the grid. As the active layer represents the river bed, it has a variable thickness between 25 and $150 \%$ of the stratum thickness. Erosion removes sediment and causes the active layer thickness to decrease. If the thickness becomes less than a threshold value, then the upper stratum is incorporated in the active layer to form a new, thicker active layer. Conversely, deposition adds material to the active layer, causing it to grow. If the active layer becomes greater than a set value a new stratum is created, leaving a thinner active layer.

Limited slope processes are also included, with mass movement when a critical slope threshold is exceeded, together with soil creep. These allow material from slopes to be fed into the fluvial system as well as the input from landslides (both large scale and small - e.g. bank collapse). After the fluvial erosion/deposition and slope process amounts are calculated, the elevations and grain size properties of the cells are updated simultaneously.

\section{Integration of climate and geomorphic models}

In this study we model how the River Swale in northern England responds to simulated changes in rainfall under climate change. The Swale is an upland catchment of $186 \mathrm{~km}^{2}$ (Fig. 1) with $500 \mathrm{~m}$ of relative relief. The catchment is underlain by a mixture of coarse sandstones overlying carboniferous limestone and was glaciated during the last glacial 


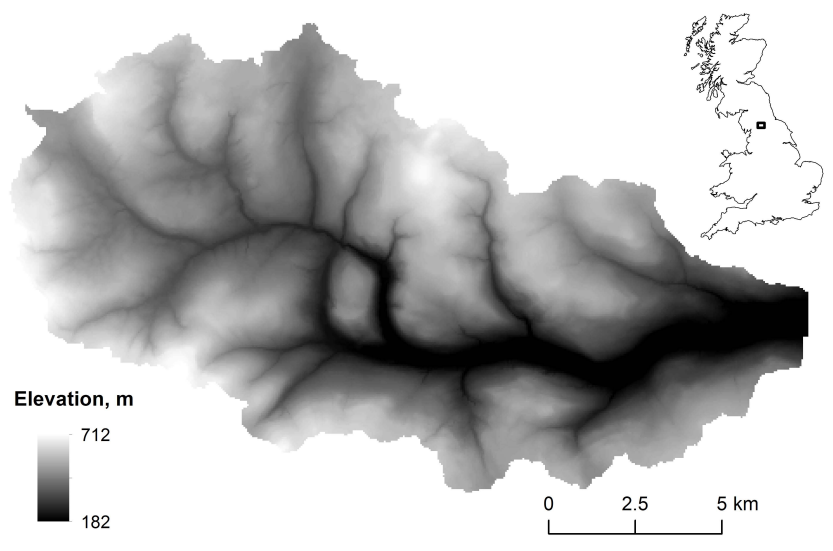

Fig. 1. The catchment of the River Swale, Yorkshire, UK.

period. The river is cobble/gravel bedded with rough grazing and pastoral agriculture the main land use. The Swale is the focus of previous studies using the CAESAR model (Coulthard et al., 2005; Coulthard and Macklin, 2001, 2003) and being an upland catchment is an important source of coarse sediment and the primary supplier of fine sediment to downstream fluvial systems (Walling et al., 1999) and thus is an appropriate choice for this illustrative study.

CAESAR was set up using a 50m digital elevation model (DEM) of the catchment, with a secondary DEM representing bedrock sections of the channel (in some of the tributaries) that restrict channel incision in these areas. The main driver for CAESAR is hourly rainfall data and therefore $30-\mathrm{yr}$ sequences of simulated hourly rainfall were generated using the UKCP09 weather generator for 5 contiguous tiles that overlay the catchment. Each CAESAR model run took 12$48 \mathrm{~h}$ to complete, depending upon the number and size of rainfall events within each simulation. The computationally intensive nature of this study meant that only 10030 -yr CFs per scenario were analysed in this initial study. Although this does not cover the full uncertainty range of the UKCP09 future climate projections, it provides the most comprehensive study yet of the range of uncertainty in climate change impacts on future sediment delivery and channel change, and is in line with the UKCP09 guidance of using a minimum of 100 random samples of the 10000 sets of change factors to maintain the representativeness of the sampled dataset.

We produce scenarios for 3 different $30-\mathrm{yr}$ time slices centred on the 2020s (2010-2039), 2050s (2040-2069) and 2080s (2070-2099), for each of the Low, Medium and High emissions scenarios. For convenience these will be subsequently referred to as the "nine scenarios". For each future period 100 sets of CFs were sampled from the UKCP09 projections and used to perturb the observed statistics to generate a synthetic 30 -yr hourly rainfall series for each set. A set of 10030 -yr simulations was also produced for the baseline period 1961-1990 against which to assess the future projections. The baseline period is fitted using observed statistics for 1961-1990. Note that variations in the baseline simulations represent solely the stochastic nature of the UKCP09 Weather Generator and can be thought of as an estimate of stochastic or "natural climate variability" against which to compare the projected changes (which contain stochastic variability as well as changes consistent with the climate projections they are based upon). For each of the nine rainfall scenarios, 100 30-yr daily simulations were then carried out with the CAESAR model, simulating daily sediment and water discharges.

A final step in setting up the simulations was to establish that the baseline rainfall data from 1961-1990 was representative for the area in terms of the river flows produced. This was achieved by comparing data from a flow gauge at Catterick Bridge to CAESAR simulated flows. As Catterick Bridge is $20 \mathrm{~km}$ downstream from the area simulated here this required extending the DEM to increase the catchment area accordingly. However, it was necessary to use the smaller catchment area for the geomorphic simulations as increasing the catchment area to Catterick (250\%) significantly increased CAESAR model run times. Figure 2a shows 30-yr hydrographs from CAESAR for five randomly selected baseline rainfall datasets as well as the distribution of daily total runoff totals. Observed river flow data from Catterick Bridge is plotted (Fig. 2a) along with its frequency-intensity in black (Fig. 2b). Finally, the distribution of real flow data is overlain with the results from all five baseline scenarios (Fig. 2b). The modelled and observed flow data show a good correspondence, though there is a lack of larger flood events in the observations. This can be attributed to the short length of the observed record ( $15 \mathrm{yr}$ ) compared to the $150 \mathrm{yr}$ of baseline simulated data plotted in grey.

\section{Results and discussion}

\subsection{Overall changes in sediment yield}

Figure 3 shows the sediment values for the nine scenarios and the baseline as cumulative volumes. Sharp rises in the lines indicate the presence of flood events that cause a sudden increase in sediment yield. The red line in each plot indicates the average for all 100 simulations in each scenario and the shaded cyan background indicates one standard deviation. Figure 3 demonstrates a general increase in total sediment yield with higher emissions scenarios and for later time slices, together with a slight increase in the standard deviation. However, there is considerable variability with, for example, individual runs from the Low emissions scenario for 2040-2069 having greater total sediment yields than most runs from the High emissions scenario for 2070-2099. This reflects the uncertainty in the projected climate changes for each scenario as well as the variability introduced by the stochastic nature of the simulated rainfall, and shows how 

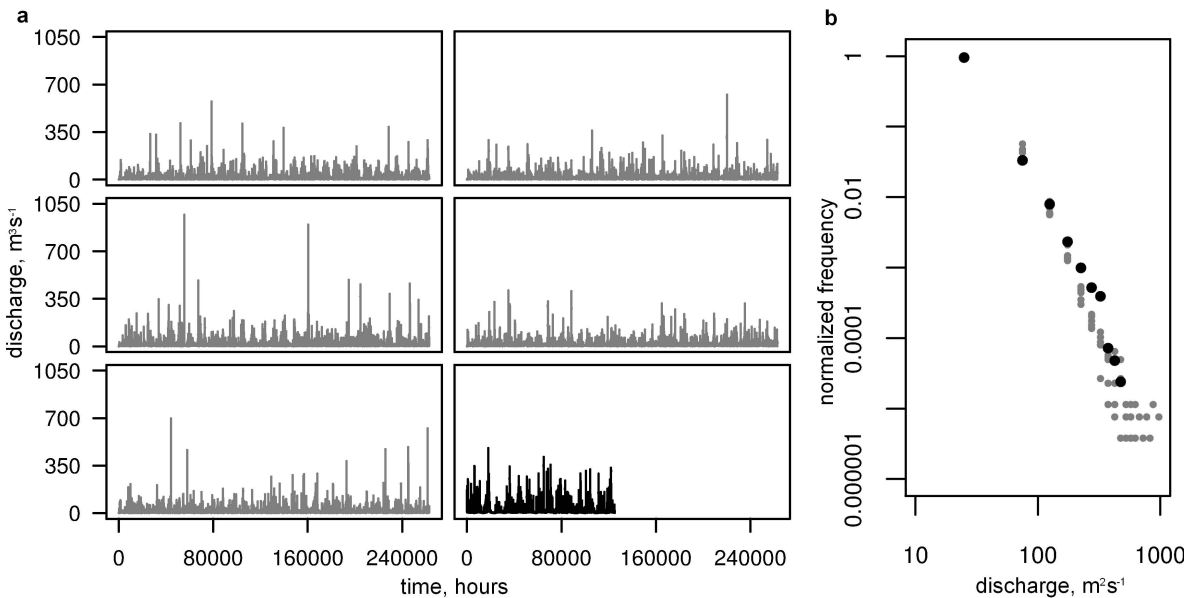

Fig. 2. Hydrographs (a) and histograms (b) from five baseline climate simulations (in grey), and observed discharge (in black). Histogram bin sizes for (b) are 50 .

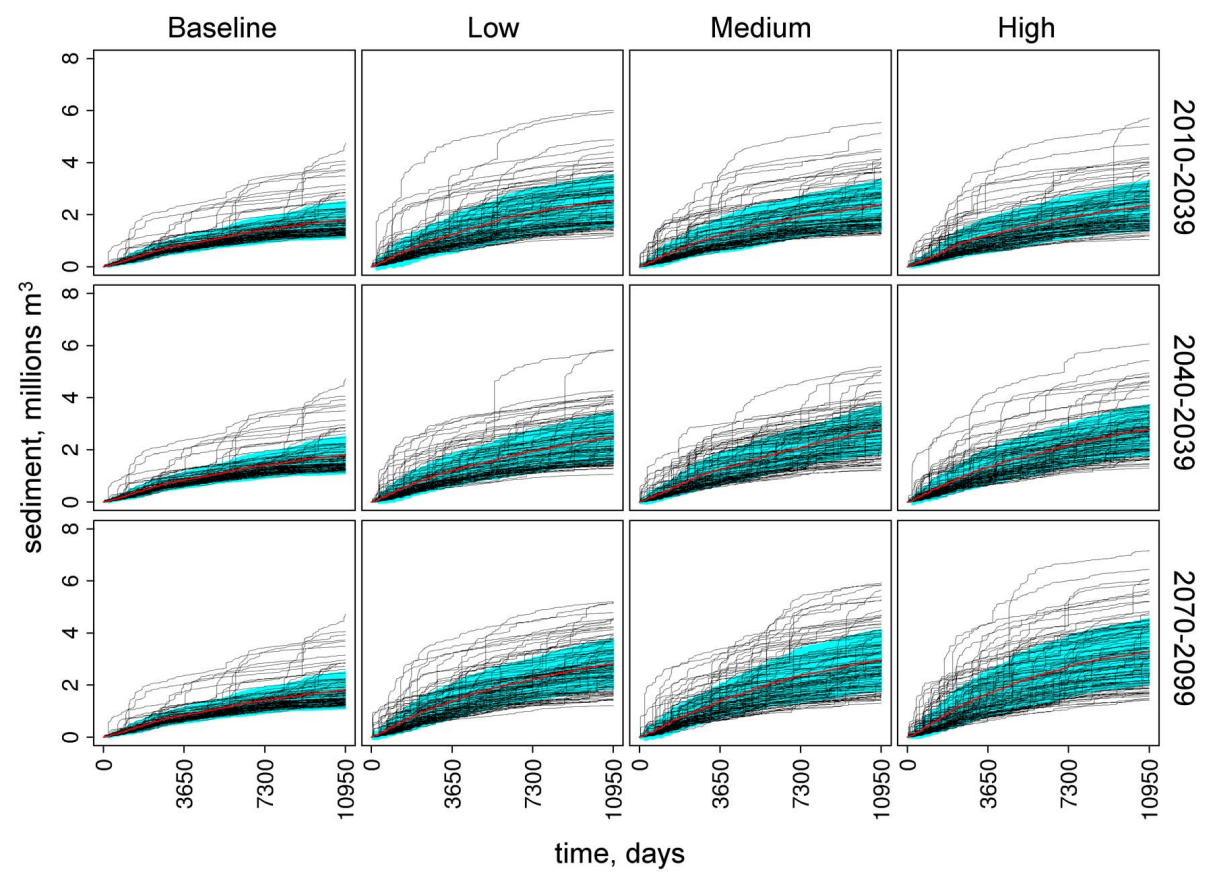

Fig. 3. Cumulative daily sediment outputs for all runs of 2010-2039, 2040-2069 and 2070-2099 (vertically) periods for the Low, Medium and High emissions scenarios (horizontally). Daily mean cumulative sediment is plotted as a red line, and daily standard deviation as cyan shading. For each time slice, the baseline climate, 1961-1990, results are plotted in the first panel for comparison.

important it is to use a probabilistic approach with an ensemble of runs for each scenario.

Figure 4 describes the mean and distribution of the total sediment yield for each of the 10030 -yr simulations for the nine scenarios. Like Fig. 3, this also illustrates the projected increase in sediment yield with increased emissions scenario and for later time slices with a $100 \%$ increase in mean sediment yield from baseline to 2070-2099 High emissions scenario. Table 1 demonstrates that sediment yields from all the climate change scenarios are significantly different from the baseline and all 2070-2099 scenarios are significantly different from all other time slices/scenarios. Figure 4 also highlights the increase in the highest sediment yields, in particular for the 2070-2099 High emissions scenario (totals greater than $5000000 \mathrm{~m}^{3}$ ). Such increases in sediment associated with climatic increases in rainfall are broadly in line with soil erosion studies (Favis-Mortlock and Guerra, 1999; Chaplot, 2007) and channel models (Verhaar et al., 2010). 
Table 1. Comparison of sediment totals using Student's t-test, with p-values adjusted for multiple comparisons (Holm, 1979). Significant differences $(p \leq 0.05)$ are in bold.

\begin{tabular}{|c|c|c|c|c|c|c|c|c|c|c|c|}
\hline & & \multirow[b]{2}{*}{ baseline } & \multicolumn{3}{|c|}{$2010-2039$} & \multicolumn{3}{|c|}{$2040-2069$} & \multicolumn{3}{|c|}{ 2070-2099 } \\
\hline & & & low & med & high & low & med & high & low & med & high \\
\hline & baseline & & $<0.001$ & $<0.001$ & $<0.001$ & $<0.001$ & $<0.001$ & $<0.001$ & $<0.001$ & $<0.001$ & $<\mathbf{0 . 0 0 1}$ \\
\hline \multirow{3}{*}{ 2010-2039 } & low & $<0.001$ & & 1.000 & 1.000 & 1.000 & 1.000 & 1.000 & 0.584 & 0.111 & $<0.001$ \\
\hline & med & $<0.001$ & 1.000 & & 1.000 & 1.000 & 0.066 & 0.072 & 0.034 & 0.005 & $<0.001$ \\
\hline & high & $<0.001$ & 1.000 & 1.000 & & 1.000 & 0.041 & 0.046 & 0.019 & 0.003 & $<\mathbf{0 . 0 0 1}$ \\
\hline \multirow{3}{*}{ 2040-2069 } & low & $<0.001$ & 1.000 & 1.000 & 1.000 & & 0.373 & 0.378 & 0.177 & 0.034 & $<0.001$ \\
\hline & med & $<0.001$ & 1.000 & 0.066 & 0.041 & 0.373 & & 1.000 & 1.000 & 1.000 & $\mathbf{0 . 0 2 7}$ \\
\hline & high & $<0.001$ & 1.000 & 0.072 & 0.046 & 0.378 & 1.000 & & 1.000 & 1.000 & 0.034 \\
\hline \multirow{3}{*}{ 2070-2099 } & low & $<0.001$ & 0.584 & 0.034 & 0.019 & 0.177 & 1.000 & 1.000 & & 1.000 & 0.064 \\
\hline & med & $<0.001$ & 0.111 & 0.005 & 0.003 & 0.034 & 1.000 & 1.000 & 1.000 & & 0.777 \\
\hline & high & $<0.001$ & $<0.001$ & $<\mathbf{0 . 0 0 1}$ & $<\mathbf{0 . 0 0 1}$ & $<0.001$ & 0.027 & 0.034 & 0.064 & 0.777 & \\
\hline
\end{tabular}

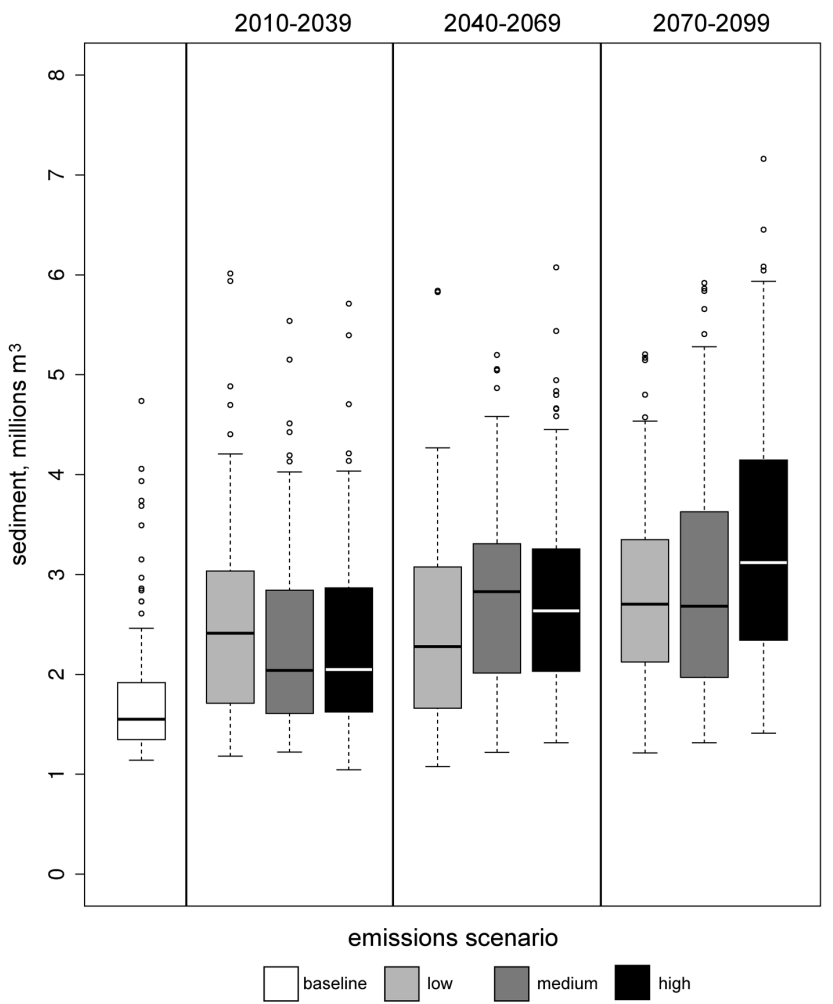

Fig. 4. Box plot showing the distribution of total sediment over 100 30-yr runs using different UKCP09 WG CFs for the 2010-2039, 2040-2069 and 2070-2099 time slices for the Low, Medium and High emissions scenarios. The baseline climate (1961-1990) is shown in white in the left hand panel; the variability in these simulations comes from stochastic variability alone.

\subsection{Event based changes in sediment yield}

The CAESAR simulations provide daily totals of sediment yields, thus it is also possible to examine how catchment sediment yield has changed on a daily event basis. Figure 5 shows histograms of daily sediment totals for all nine simulations as well as for the baseline and this shows three projected effects of climate change on sediment event distribution. Firstly, there is a general upwards displacement in the frequency of medium to large size events, with little change in the number of smaller events. Secondly, there is a notable peak in sediment delivery events of magnitude $\sim 700000 \mathrm{~m}^{3}$ in the later time slices for the High emissions scenario. Thirdly, there is a considerable increase in the magnitude and frequency of large and very large sediment yield events under the High emissions scenario which do not occur under the baseline scenario.

These three effects suggest that projected changes to rainfall magnitudes and frequencies in this part of the UK may have a profound effect on the geomorphology of the Swale catchment. Under climate change, it is projected that there will be a significant increase in the frequency of large daily sediment yields and, significantly, the appearance of several events (daily totals) that are more than twice the magnitude of the largest event found in the baseline climate simulations. In short, climate change is projected to increase the likelihood of medium and large sized sediment events and lead to the generation of very large sediment events which have not previously been recorded (in the instrumental record). Previous applications of the CAESAR model (Coulthard and Macklin, 2001; Hancock and Coulthard, 2011) have shown how sediment yield can be sensitive to increases in rainfall magnitude, but here we are able to determine what size events have the greatest impact. 


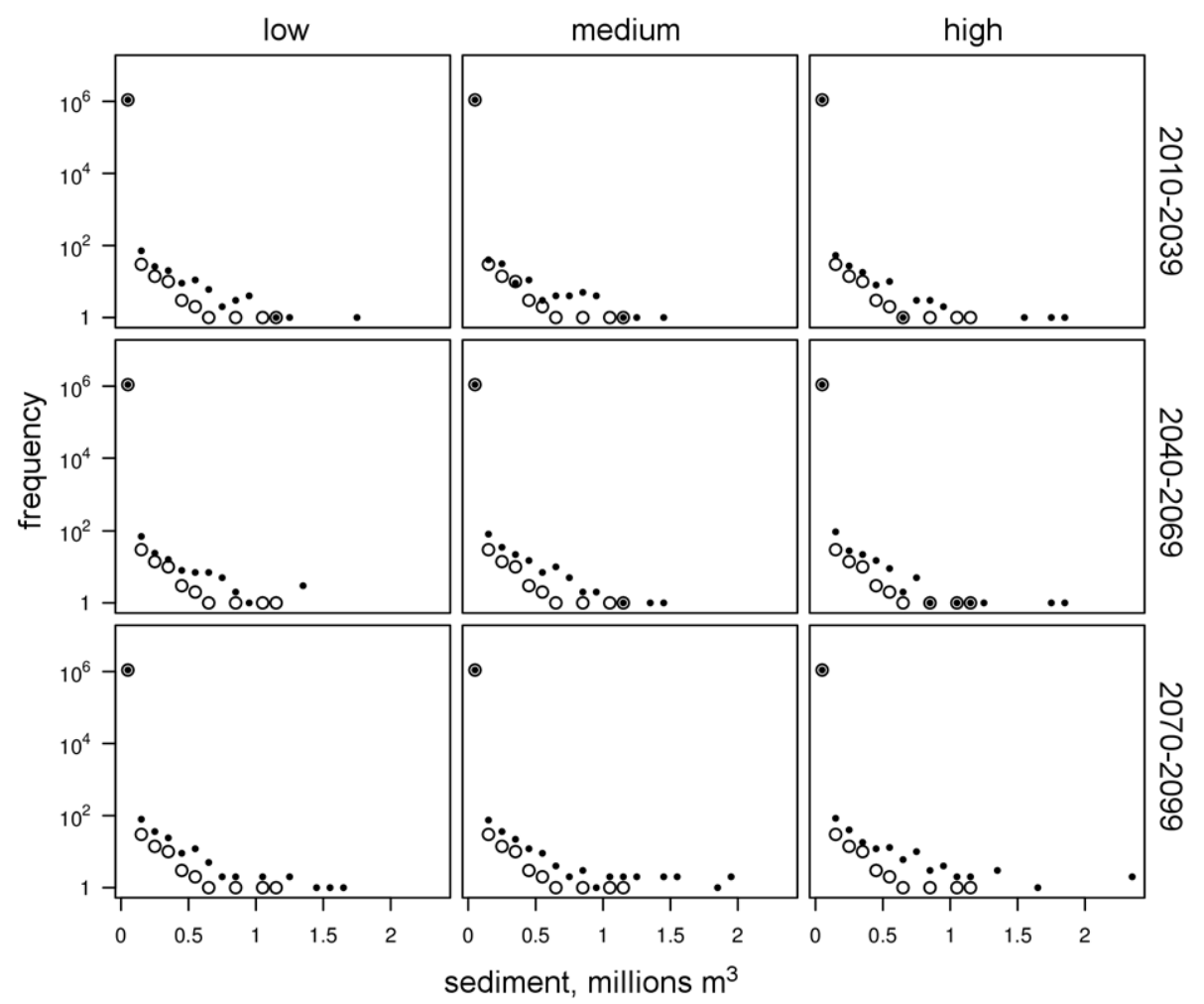

Fig. 5. Frequency plots of daily sediment totals from all nine climate change scenarios (in black), shown against results for the baseline climate, 1961-1990 (in grey). Bin sizes are 100000.

\subsection{The role of seasonality}

Figure 7 shows the projected monthly changes to rainfall under the nine scenarios. This shows that the mean projected change from the 10030 -yr runs shows a increase in winter season rainfall (from October to March) and a decrease or no change to summer season rainfall (from April to September) when compared to the baseline climate, 1961-1990, which amplifies throughout the century. Figure 6 shows that for the first time slice, 2010-2039, the emissions scenario is not important; however, which emissions trajectory we follow becomes increasingly important later this century in terms of the magnitude of projected changes to rainfall. However, there is little difference in terms of the emissions scenario for changes at the 5 th percentile but much larger differences at the upper end of the rainfall distribution (95th percentile). It is also noticeable that although the mean daily rainfall and 5th percentile of daily rainfall get drier in the summer and wetter in winter, the 95th percentile of daily rainfall shows increases for all months under almost all emissions scenarios and time slices. Figure 6 also illustrates the large variability in individual UKCP09 weather generator simulations both for the baseline - a result of stochastic variability alone and the nine scenarios - resulting from climate change uncertainty from the CFs and stochastic variability from the weather generator.

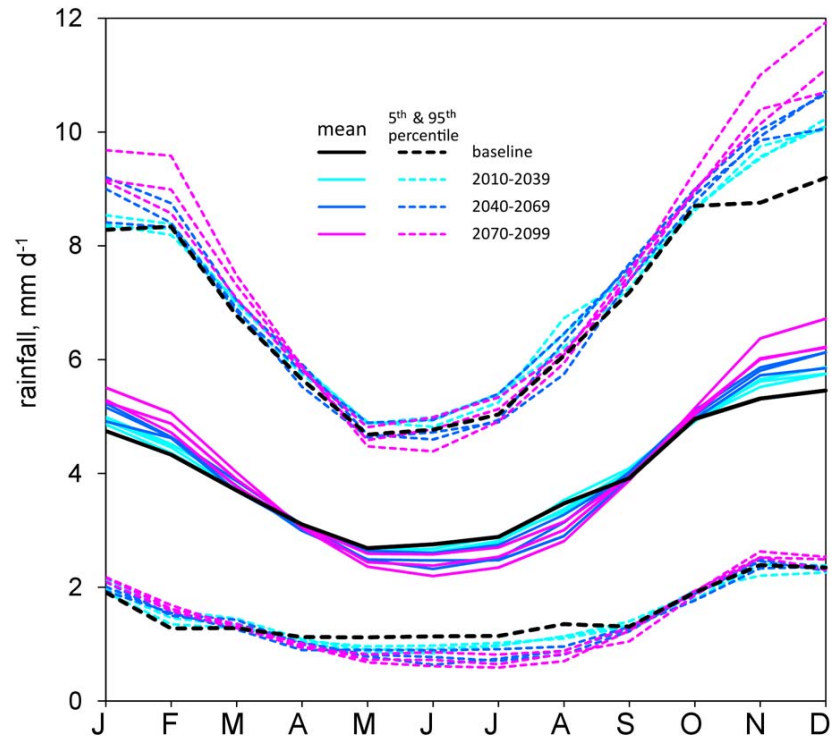

Fig. 6. Mean daily precipitation and 5 th and 95 th percentiles from the $10030-y r$ simulations for the Low, Medium, and High emissions scenarios and three time periods 2010-2029 (in cyan), 2040-2069 (in dark blue), 2070-2099 (in pink), and baseline (in black). 
To further describe how these projected seasonal changes in rainfall patterns may impact upon catchment discharge and sediment delivery we have plotted the 50th to 100th percentiles of daily rainfall totals, water discharge values and sediment yields for the 12 calendar months for the 2070 2099 time slice for all emissions scenarios. These are presented along with the same data for the baseline climate (dotted lines) in Fig. 7. This allows us to see how the magnitude of the larger (50-99th percentile) and largest (100th percentile) events has shifted between baseline and future scenario for every month. By comparing the baseline and the future scenario for rainfall, it can be seen that there is a projected increase in the frequency of larger winter events and a decrease in summer events across all percentiles. Examining the discharge and sediment yield plots the multiplier effect discussed above is apparent, with differences between the baseline and the scenario values increasing when moving from rainfall to discharge to sediment yield. In winter months there is a relatively simple change relationship between the baseline climate and the climate change scenarios, with increases across all percentiles for rainfall, discharge and sediment yield. In summer the situation is more complex. Here, there is a decrease in event size for events below the 95th percentile - a decrease in medium to large size events. However, there is an increase in the size of events for the 95th percentile and above and especially for the largest events. As you move from rain to runoff to sediment there is an increase in the gap between the 100th and 99th percentile. This is increasingly important for sediment as the sediment yield the largest event is nearly three orders of magnitude greater than the 95th percentile event. In other words, single large events are highly significant in the volume of material moved or geomorphic work done.

\subsection{Extreme (annual maximum) events}

To further explore the projected changes to the upper end of the rainfall intensity distribution and the amplification effect this has upon extreme flows and then the largest sediment delivery events, we extracted the daily annual maxima from the 100 30-yr time series for the baseline climate (19611990) and the 9 future scenarios for (a) rainfall, (b) discharge and (c) total sediment. We then examined the percentiles of the annual maximum distribution, 5th, 10th, 50th, 90th and 95th. This is shown in Table $2 \mathrm{a}$ for rainfall, Table $2 \mathrm{~b}$ for discharge and Table $2 \mathrm{c}$ for total sediment. It can be seen from Table 2 how the change is in each case positive between the baseline and the future scenario for each percentile. Also apparent is the larger projected changes for the more extreme events, i.e. for the 90th and 95th percentiles and the amplification effect of this change when moving through from rainfall to discharge to sediment delivery.

This was further explored by plotting the median, 5th and 95th percentiles of each 30-yr simulation for the baseline climate and the 2070-2099 High emissions scenario on a
Table 2. Percentiles of the annual maximum distribution for the baseline and 9 future scenarios for (a) daily rainfall ( $\mathrm{mm})$, (b) discharge $\left(\mathrm{m}^{3} \mathrm{~s}^{-1}\right)$ and (c) total sediment yield $\left(\mathrm{m}^{3}\right)$.

\begin{tabular}{lrrrrr}
\hline $\begin{array}{l}\text { (a) Annual maxima of } \\
\text { daily rainfall (mm) }\end{array}$ & $5 \%$ & $10 \%$ & $50 \%$ & $90 \%$ & $95 \%$ \\
\hline Baseline & & & & & \\
2010-2039 Low & 33.8 & 36.3 & 47.8 & 68.6 & 77.6 \\
2010-2039 Medium & 35.4 & 37.2 & 51.0 & 75.7 & 86.3 \\
2010-2039 High & 34.5 & 37.5 & 50.5 & 75.3 & 88.0 \\
2030-2069 Low & 35.0 & 37.9 & 51.7 & 74.9 & 85.1 \\
2030-2069 Medium & 35.9 & 38.6 & 52.8 & 79.8 & 86.3 \\
2030-2069 High & 36.6 & 39.6 & 54.0 & 81.3 & 92.9 \\
2070-2099 Low & 36.6 & 39.5 & 54.0 & 80.7 & 92.1 \\
2070-2099 Medium & 36.7 & 39.7 & 54.1 & 80.3 & 92.7 \\
2070-2099 High & 38.4 & 41.4 & 57.2 & 87.9 & 102.2 \\
\hline (b) Annual maxima of & $5 \%$ & $10 \%$ & $50 \%$ & $90 \%$ & $95 \%$ \\
daily discharge (m $\left.{ }^{3}{ }^{-1}\right)$ & & & & & \\
\hline Baseline & 30.6 & 33.9 & 50.8 & 82.4 & 97.6 \\
2010-2039 Low & 32.1 & 35.3 & 55.1 & 95.6 & 118.0 \\
2010-2039 Medium & 32.8 & 36.7 & 55.8 & 93.9 & 116.5 \\
2010-2039 High & 32.6 & 36.5 & 55.5 & 95.1 & 115.2 \\
2030-2069 Low & 33.0 & 36.6 & 57.2 & 96.7 & 117.1 \\
2030-2069 Medium & 33.5 & 37.4 & 58.0 & 104.5 & 129.3 \\
2030-2069 High & 34.4 & 38.9 & 60.7 & 106.7 & 127.9 \\
2070-2099 Low & 34.5 & 38.8 & 60.2 & 106.7 & 130.1 \\
2070-2099 Medium & 35.0 & 38.9 & 61.2 & 107.1 & 128.4 \\
2070-2099 High & 37.0 & 42.3 & 67.1 & 120.1 & 140.8 \\
\hline (c) Annual maxima of & $5 \%$ & $10 \%$ & $50 \%$ & $90 \%$ & $95 \%$ \\
daily total sediment yield $\left(\mathrm{m}^{3}\right.$ ) & & & & & \\
\hline Baseline & 411 & 604 & 2243 & 12816 & 29548 \\
2010-2039 Low & 534 & 733 & 2899 & 24536 & 74388 \\
2010-2039 Medium & 531 & 749 & 2832 & 22125 & 62426 \\
2010-2039 High & 561 & 786 & 2810 & 20975 & 54020 \\
2030-2069 Low & 580 & 816 & 3102 & 24733 & 71761 \\
2030-2069 Medium & 710 & 917 & 3312 & 33192 & 104123 \\
2030-2069 High & 689 & 945 & 3515 & 35275 & 99128 \\
2070-2099 Low & 647 & 895 & 3473 & 38659 & 97611 \\
2070-2099 Medium & 638 & 923 & 3701 & 32516 & 91743 \\
2070-2099 High & 729 & 1057 & 4338 & 50352 & 125886 \\
\hline & & & & & \\
& & & & & \\
\hline
\end{tabular}

Gumbel reduced variate plot to estimate approximate return periods for events for the baseline and how these might change for rainfall, discharge and sediment (Fig. 8). Figure 8 demonstrates that although the distributions overlap, the median annual maxima events are larger in all cases for the future case when compared to the baseline and that the changes are largest at the high return periods. Also apparent is how the catchment acts as a geomorphic multiplier - with the the amplification of the signal from rainfall to discharge to sediment delivery. This is best illustrated by the changing ratio of the $\sim 50$-yr return period to the 2 -yr return (details given in Table 3). The 2 to $50 \mathrm{yr}$ return ratio for daily rainfall is 1.78 for baseline, increasing to 1.92 in the 2070-2099 High future scenario. For discharge the figures are 2.25 and 2.53, but for sediment the ratios are 32.89 and 84.44 . Therefore, the amplification effect from rain to discharge to sediment is even more exaggerated in high return period events. 

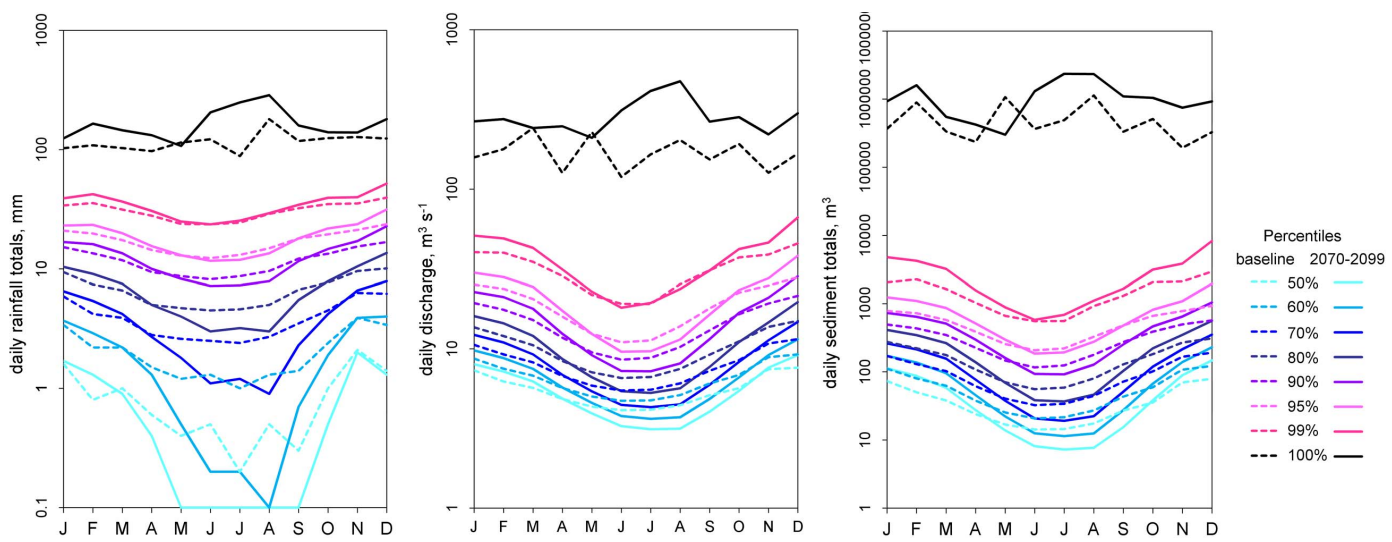

Fig. 7. Percentiles of daily rainfall, discharge and sediment totals per month for the baseline climate (1961-1990) and the High emissions scenario (2070-2099).
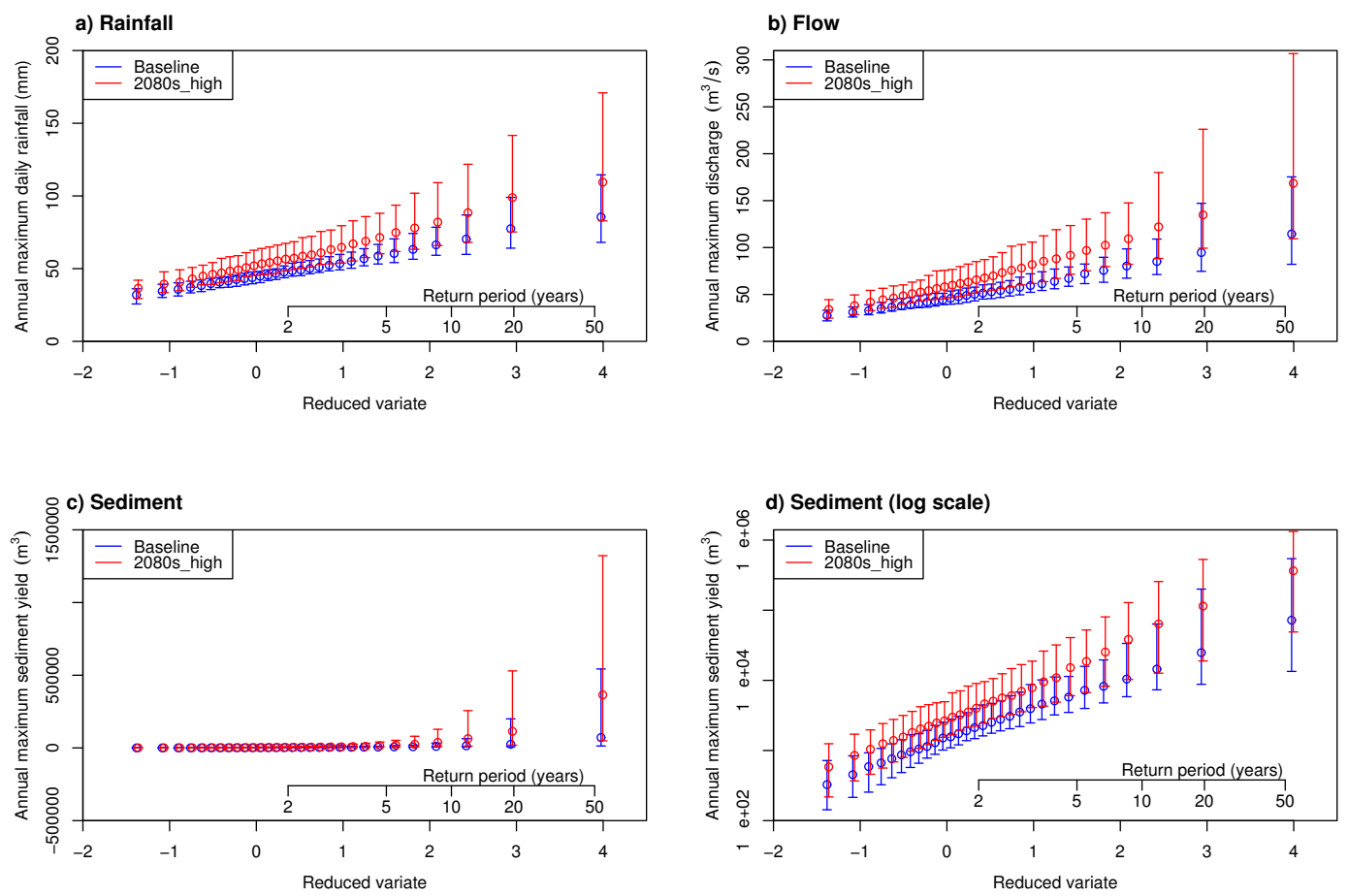

Fig. 8. Gumbel reduced variate plot of (a) annual maximum daily rainfall $(\mathrm{mm})$, (b) annual maximum discharge $\left(\mathrm{m}^{3} \mathrm{~s}^{-1}\right),(\mathbf{c})$ annual maximum sediment yield $\left(\mathrm{m}^{3}\right)$, (d) annual maximum sediment yield $\left(\mathrm{m}^{3}\right)$ on a log scale. For each of the 30 -yr runs, for the baseline (blue) and High emissions 2070-2099 scenario (red), the median annual maximum event is plotted as a circle with the error bars showing the 5 th and 95 th percentiles from the 100 simulations. Return periods are shown on the y-axis.

Furthermore, if we look at the ratio between baseline and 2070-2099 High scenarios for rainfall the 2-yr and 50yr rainfall events increase at approximately the same rate (1.18 and 1.28, respectively). But for sediment delivery there is a staggering five-fold increase (5.07) between baseline and 2080-2099 High scenarios at the 50-yr return period compared to a modest 1.97 ratio increase at the 2 -yr return period. In summary, for the 2070-2099 scenario, rainfall for 50 yr return period events will be 1.28 times greater than baseline values, but the associated sediment yields are predicted to be 5 times larger.

\subsection{Limitations}

Although the approach is state-of-the-art, there are still limitations to the methods taken here. The hourly rainfall data generated by the UKCP09 weather generator is lumped over the whole catchment and whilst the catchment is not especially large and rainfall variability may not be great, there 
Table 3. Estimated $\sim 50$ and $2-y r$ return periods for daily rainfall $(\mathrm{mm})$, discharge $\left(\mathrm{m}^{3} \mathrm{~s}^{-1}\right)$ and total sediment $\left(\mathrm{m}^{3}\right)$ for the baseline and 2070-2099 high emissions scenario showing the changing ratio between the return periods.

\begin{tabular}{|c|c|c|c|}
\hline & Baseline & High 2070-2099 & Ratio \\
\hline \multicolumn{4}{|c|}{ Rainfall (mm) } \\
\hline $2 \mathrm{yr}$ & 48.1 & 56.9 & 1.18 \\
\hline$\sim 50 \mathrm{yr}$ & 85.6 & 109.5 & 1.28 \\
\hline Ratio & 1.78 & 1.92 & \\
\hline \multicolumn{4}{|c|}{ Discharge $\left(\mathrm{m}^{3} \mathrm{~s}^{-1}\right)$} \\
\hline $2 \mathrm{yr}$ & 50.8 & 66.6 & 1.31 \\
\hline$\sim 50 \mathrm{yr}$ & 114.4 & 168.5 & 1.47 \\
\hline Ratio & 2.25 & 2.53 & \\
\hline \multicolumn{4}{|c|}{ Sediment $\left(m^{3}\right)$} \\
\hline $2 \mathrm{yr}$ & 2189.4 & 4320.2 & 1.97 \\
\hline$\sim 50 \mathrm{yr}$ & 72016.8 & 364779.3 & 5.07 \\
\hline Ratio & 32.89 & 84.44 & \\
\hline
\end{tabular}

would be some temporal, spatial and altitudinal variability that could impact upon the study results.

Each 30-yr simulation took between 18 and $36 \mathrm{~h}$ (depending on the size of events) and ultimately the availability of computational time restricted the number of simulations we could carry out. Our sensitivity analysis for the baseline data indicated that $60-100$ repeats were required in order for the means and standard deviations to stabilise - to account for the stochastic nature of the weather generator (see Fig. A1). However, each scenario rainfall simulation from the weather generator represents not only a stochastically chosen series of events but also changes in the climate model parameters used to simulate the future climate. Therefore, if there are 100 changes in climate model parameters per scenario, ideally we would require 100 repeats for each of these 100 . This would push the required computation time to c. 100000 days. Parallel approaches and the use of GPU methods makes this problem more tractable but at present the time/resources required is simply too great. Therefore, the results other than the baseline simulation represent a combination of randomly sampled parameter values for the future climate model and the stochastic component.

\section{Conclusions}

For the first time, we are able to meaningfully simulate the potential impacts of anthropogenic climate change on catchment geomorphology and sediment yield. The results are clear and the implications concerning. Mean rainfall is projected to increase and this effect is multiplied through its translation into catchment runoff and in turn sediment yield. A $100 \%$ increase in sediment yield is projected between the baseline and the 2070-2099 High emissions scenario. For individual events, major increases in the size of medium, large and especially very large sediment delivery events are projected. Seasonally, this is linked to increases in the size of winter rainfall, discharge and sediment events across all percentiles of the distribution, but also to an increase in the largest summer rainfall events and therefore flood events. Strikingly, the extreme event analysis shows that the geomorphic multiplier affects large events to an even greater extent and that sediment yields from 50-yr return period events may be five times greater.

The projected changes described above are based on the means of 100 simulations per scenario and it is important to note that not only is there an increase in the mean value with climate change - individual events show far greater projected changes than the $100 \%$ increases in sediment yield.

For those managing, or living near, upland UK rivers the implications of these results are highly significant. Increased flood sizes and sediment yields may have an important impact on the fluvial environment. Increased bed load yields can lead to channel siltation, instability and channel pattern change. This can lead to the undermining or erosion of bridges, flood defences and channel control structures. For flood defence there is a double impact. Not only is there projected to be a greater number of larger events, but also the deposition of large volumes of coarse sediment will also negatively alter the capability of a river to convey flood waters, thus raising the stage for subsequent flood events. Ecologically, changes in coarse and fine grain sediment delivery will impact fisheries both in the uplands and in lowland water courses. Benefits may be both positive and negative as there may be increases in areas of medium/coarse grain size habitats as well as the deterioration of others through siltation. It is worth remembering, however, that the results show changes in probabilities and whilst some scenario simulations showed massive, potentially catastrophic, changes (far greater than the means discussed above), some showed none if any change.

Finally, there are high levels of parameter and model uncertainty at all stages of the modelling exercise, from GCM output to sediment yield, and the systems modelled are highly non-linear. Having undertaken this exercise, we find it hard to justify making any sort of future projection based on a few simulations, as identical "scenario" runs can generate very little, or catastrophic levels of change. Therefore, we urge the geomorphic modelling community to embrace using a probabilistic approach based on multiple repeat simulations. 


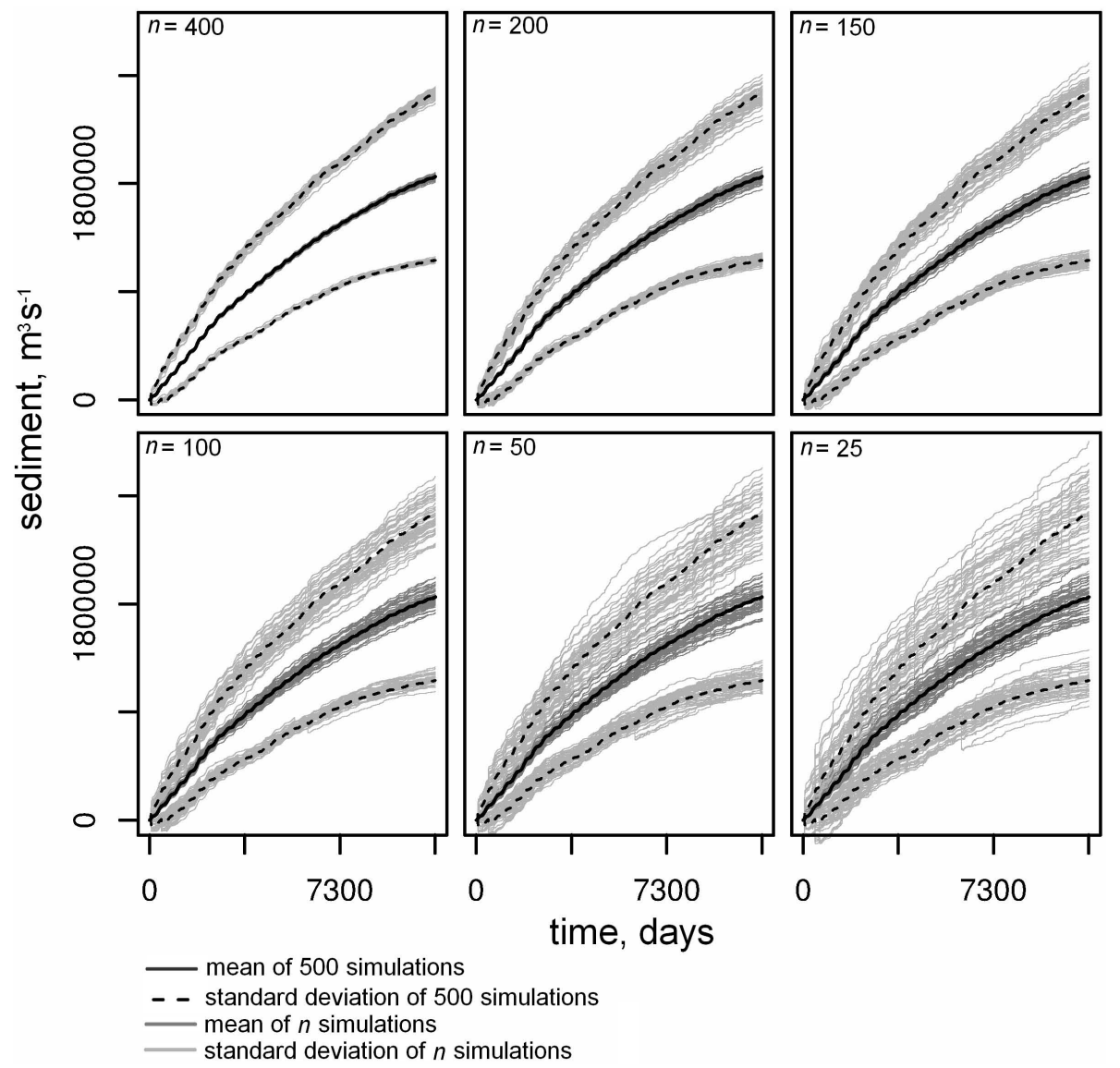

Fig. A1. Cumulative daily sediment mean (solid black) and standard deviation (dashed) from 500 baseline simulations overlaid on cumulative daily sediment mean (dark grey) and standard deviation (light grey) from $n$ randomly selected baseline simulations.

50 replicates are shown in each plot.

Acknowledgements. This work was supported by a NERC post-doctoral Fellowship award to H. Fowler (2006-2010) NE/D009588/1. We would like to thank Aidan Burton at Newcastle University for producing Fig. 8 and the work on return period ratios. The CAESAR model is freely distributed from http://www.coulthard.org.uk and from http://code.google.com/p/caesar-lisflood/.

Edited by: H. Cloke

\section{References}

Arnold, J. G., Srinivasan, R., Muttiah, R. S., and Williams, J. R.: Large area hydrologic modeling and assesment part I: model devlopment, J. Am. Water Resour. Assoc., 34, 73-89, 1998.

Beven, K.: A physically based, variable contributing area model of basin hydrology, Bull. Int. Assoc. Sci. Hydrol., 24, 43-69, 1979.

Burton, A., Glenis, V., Bovolo, C. I., Blenkinsop, S., Fowler, H. J., and Kilsby, C. G.: Stochastic rainfall modelling for the assessment of urban flood hazard in a changing climate, British Hydrological Society Third International Symposium, 19-23 July 2010, Newcastle upon Tyne, UK, 2010.
Burton, A., Kilsby, C. G., Fowler, H. J., Cowpertwait, P. S. P., and O'Connell, P. E.: RainSim: A spatial temporal stochastic rainfall modelling system, Environ. Model. Softw., 23, 1356-1369, 2008.

Chaplot, V.: Water and soil resources response to rising levels of atmospheric $\mathrm{CO}_{2}$ concentration and to changes in precipitation and air temperature, J. Hydrol., 337, 159-171, 2007.

Christierson, B. V., Vidal, J.-P., and Wade, S. D.: Using UKCP09 probabilistic climate information for UK water resource planning, J. Hydrol., 424-425, 48-67, 2012.

Coulthard, T. J. and Macklin, M. G.: How sensitive are river systems to climate and land-use changes? A model-based evaluation, J. Quaternary Sci., 16, 347-351, 2001.

Coulthard, T. J. and Macklin, M. G.: Modeling long-term contamination in river systems from historical metal mining, Geology, 31, 451-454, 2003.

Coulthard, T. J. and Van De Wiel, M. J.: Quantifying fluvial non linearity and finding self organized criticality? Insights from simulations of river basin evolution, Geomorphology, 91, 216-235, 2007. 
Coulthard, T. J., Kirkby, M. J., and Macklin, M. G.: Modelling geomorphic response to environmental change in an upland catchment, Hydrol. Process., 14, 2031-2045, 2000.

Coulthard, T. J., Macklin, M. G., and Kirkby, M. J.: A cellular model of Holocene upland river basin and alluvial fan evolution, Earth Surf. Proc. Land., 27, 269-288, 2002.

Coulthard, T. J., Lewin, J., and Macklin, M. G.: Modelling differential catchment response to environmental change, Geomorphology, 69, 222-241, 2005.

Covey, C., Achuta Rao, K. M., Cubasch, U., Jones, P., Lambert, S. J., Mann, M. E., Phillips, T. J., and Taylor, K. E.: An overview of results from the Coupled Model Intercomparison Project, Global Planet. Change, 37, 103-133, 2003.

Cowpertwait, P. S. P.: Further developments of the Neyman-Scott clustered point process for modelling rainfall, Water Resour. Res., 27, 1431-1438, 1991.

Cudden, J. R. and Hoey, T. B.: The causes of bedload pulses in a gravel channel: the implications of bedload grain-size distributions, Earth Surf. Proc. Land., 28, 1411-1428, 2003.

Dankers, R. and Feyen, L.: Climate change impact on flood hazard in Europe: An assessment based on high-resolution climate simulations, J. Geophys. Res., 113, D19105, doi:10.1029/2007JD009719, 2008.

Déqué, M., Rowell, D. P., Lüthi, D., Giorgi, F., Christensen, J. H., Rockel, B., Jacob, D., Kjellström, E., de Castro, M., and van den Hurk, B.: An intercomparison of regional climate simulations for Europe: assessing uncertainties in model projections, Climatic Change, 81(Supplement 1), 53-70, 2007.

Douville, H., Chauvin, F., Planton, S., Royer, J. F., and Salas-Melia, D., and Tyteca, S.: Sensitivity of the hydrological cycle to increasing amounts of greenhouse gases and aerosols, Clim. Dynam., 20, 45-68, 2002.

Dutta, D., Herath, S., and Musiake, K.: A mathematical model for flood loss estimation, J. Hydrol., 277, 24-49, 2003.

Einstein, H. A.: The bed-load function for sediment transportation in open channel flows, US Dept. of Agriculture, Washington, 1950.

Ekstrom, M., Fowler, H. J., Kilsby, C. G., and Jones, P. D.: New estimates of future changes in extreme rainfall across the UK using regional climate model integrations, 2. Future estimates and use in impact studies, J. Hydrol., 300, 234-251, 2005.

Elía, R., Caya, D., Côté, H., Frigon, A., Biner, S., Giguère, M., Paquin, D., Harvey, R., and Plummer, D.: Evaluation of uncertanties in the CRCM-simulated North American climate, Clim. Dynam., 30, 113-132, 2008.

Elliott, A. H., Oehler, F., Schmidt, J., and Ekanayake, J. C.: Sediment modelling with fine temporal and spatial resolution for a hilly catchment, Hydrol. Process., 26, 3645-3660, doi:10.1002/hyp.8445, 2012.

Favis-Mortlock, D. T. and Guerra, A. J. T.: The implications of general circulation model estimates of rainfall for future erosion: a case study from Brazil, Catena, 37, 329-354, 1999.

Feyen, L., Dankers, R., Bodis, K., Salamon, P., and Barredo, J. I.: Fluvial flood risk in Europe in present and future climates, Climatic Change, 112, 47-62, doi:10.1007/s10584-011-0339-7, 2011.

Fowler, H. J. and Ekström, M.: Multi-model ensemble estimates of climate change impacts on UK seasonal precipitation extremes, Int. J. Climatol., 29, 385-416, 2009.
Fowler, H. J., Blenkinsop, S., and Tebaldi, C.: Linking climate change modelling to impact studies: recent advances in downscaling techniques for hydrological modelling, Int. J. Climatol., 27, 1547-1578, 2007.

Giorgi, F. and Francisco, R.: Evaluating uncertainties in the prediction of regional climate change, Geophys. Res. Lett., 27, 12951298, 2000.

Gomez, B. and Church, M.: An assessment of bed load sediment transport formulae for gravel bed rivers, Water Resour. Res., 25, 1161-1186, 1989.

Gomez, B., Mertes, L. A. K., Phillips, J. D., Magilligan, F. J., and James, L. A.: Sediment characteristics of an extreme flood - 1993 upper Mississippi river valley, Geology, 23, 963-966, 1995.

Gomez, B., Cui, Y., Kettner, A. J., Peacock, D. H., and Syvitski, J. P. M.: Simulating changes to the sediment transport regime of the Waipaoa River, New Zealand, driven by climate change in the twenty-first century, Global Planet. Change, 67, 153-166.2009.

Hancock, G. R.: A catchment scale assessment of increased rainfall and storm intensity on erosion and sediment transport for Northern Australia, Geoderma, 152, 350-360, 2009.

Hancock, G. R. and Coulthard, T. J.: Channel movement and erosion response to rainfall variability in southeast Australia, Hydrol. Process., 26, 663-673, 2011.

Holm, S.: A simple sequentially rejective multiple test procedure, Scand. J. Stat., 6, 65-70, 1979.

Jerolmack, D. J. and Paola, C.: Shredding of environmental signals by sediment transport, Geophys. Res. Lett., 37, L19401, doi:10.1029/2010GL044638, 2010.

Jones, P. D., Kilsby, C. G., Harpha, C., Glenis, V., and Burton, A.: UK Climate Projections science report: Projections of future daily climate for the UK from the Weather Generator, University Of Newcastle, UK., 48 pp., 2009.

Kilsby, C. G., Jones, P. D., Burton, A., Ford, A. C., Fowler, H. J., Harpham, C., James, P., Smith, A., and Wilby, R. L.: A daily weather generator for use in climate change studies, Environ. Model. Softw., 22, 1705-1719, doi:10.1016/j.envsoft.2007.02.005, 2007.

Kleinen, T. Petschel-Held, G.: Integrated assessment of changes in flooding probabilities due to climate change, Climatic Change, 81, 283-312, 2007.

Laflen, J. M., Elliot, W. J., Flanagan, D. C., Meyer, C. R., and Nearing, M. A.: WEPP-Predicting water erosion using a processbased model, J. Soil Water Conserv., 52, 96-102, 1997.

Lane, S. N., Tayefi, V., Reid, S. C., Yu, D., and Hardy, R. J.: Interactions between sediment delivery, channel change, climate change and flood risk in a temperate upland environment, Earth Surf. Proc. Land., 32, 429-446, 2007.

Macklin, M. G., Jones, A. F., and Lewin, J.: River response to rapid Holocene environmental change: evidence and explanation in British catchments, Quaternary Sci. Rev., 29, 1555-1576, 2010.

Magilligan, F. J., Phillips, J. D., James, L. A., and Gomez, B.: Geomorphic and sedimentological controls on the effectiveness of an extreme flood, J. Geol., 106, 87-95, 1998.

Mayes, W. M., Walsh, C. L., Bathurst, J. C., Kilsby, C. G., Quinn, R. F., Wilkinson, M. E., Daugherty, A. J., and O'Connell, P. E.: Monitoring a flood event in a densely instrumented catchment, the Upper Eden, Cumbria, UK, Water Environ. J., 20, 217-226, 2006. 
Merritt, W. S., Letcher, R. A., and Jakeman, A. J.: A review of erosion and sediment transport models, Environ. Model. Softw., 18, 761-799, 2003.

Milan, D. J.: Geomorphic impact and system recovery following an extreme flood in an upland stream: Thinhope Burn, northern England, UK, Geomorphology, 138, 319-328, 2012.

Milly, P. C. D., Wetherald, R. T., Dunne, K. A., and Delworth, T. L.: Increasing risk of great floods in a changing climate, Nature, 415, 514-517, 2002.

Murphy, J. M., Sexton, D. M. H., Barnett, D. N., Jones, G. S., Webb, M. J., Collins, M., and Stainforth, D. A.: Quantification of modelling uncertainties in a large ensemble of climate change simulations, Nature, 429, 768-772, 2004.

Murphy, J. M., Sexton, D. M. H., Jenkins, G. J., Boorman, P. M., Booth, B. B. B., Brown, C. C., Clark, R. T., Collins, M., Harris, G. R., Kendon, E. J., Betts, R. A., Brown, S. J., Howard, T. P., Humphrey, K. A., McCarthy, M. P., McDonald, R. E., Stephens, A., Wallace, C., Warren, R., Wilby, R., and Wood, R. A.: UK Climate Projections Science Report: Climate change projections, Met Office Hadley Centre, Exeter, 2009.

Nearing, M. A., Jetten, V., Baffaut, C., Cerdan, O., Couturier, A., Hernandez, M., Le Bissonnais, Y., Nichols, M. H., Nunes, J. P., Renschler, C. S., Souchere, V., and van Oost, K.: Modeling response of soil erosion and runoff to changes in precipitation and cover, Catena, 61, 131-154, 2005.

Nunes, J. P. and Nearing, M. A.: Modelling Impacts of Climatic Change: Case Studies using the New Generation of Erosion Models, in: Handbook of Erosion Modelling, John Wiley \& Sons, Ltd, 289-312, 2011.

Nunes, J. P., Seixas, J., and Pacheco, N. R.: Vulnerability of water resources, vegetation productivity and soil erosion to climate change in Mediterranean watersheds, Hydrol. Process., 22, 3115-3134, 2008.

O’Neal, M. R., Nearing, M. A., Vining, R. C., Southworth, J., and Pfeifer, R. A.: Climate change impacts on soil erosion in Midwest United States with changes in crop management, Catena, 61, 165-184, 2005.

Pall, P., Aina, T., Stone, D. A., Stott, P. A., Nozawa, T., Hilberts, A. G. J., Lohmann, D., and Allen, M. R.: Anthropogenic greenhouse gas contribution to flood risk in England and Wales in autumn 2000, Nature, 470, 382-385, 2011.

Palmer, T. N. and Ralsanen, J.: Quantifying the risk of extreme seasonal precipitation events in a changing climate, Nature, 415, 512-514, 2002.

Prudhomme, C., Reynard, N., and Crooks, S.: Downscaling of global climate models for flood frequency analysis: Where are we now?, Hydrol. Process., 16, 1137-1150, 2002.

Prudhomme, C., Jakob, D., and Svensson, C.: Uncertainty and climate change impact on the flood regime of small UK catchments, J. Hydrol., 277, 1-23, 2003.

Pruski, F. F. and Nearing, M. A.: Climate-induced changes in erosion during the 21 st century for eight U.S. locations, Water Resour. Res., 38, 1298, doi:10.1029/2001WR000493, 2002.

Rummukainen, M., Räisänen, J., Bringfelt, B., Ullerstig, A., Omstedt, A., Willen, U., Hansson, U., and Jones, C.: A regional climate model for northern Europe: model description and results from the downscaling of two GCM control simulations, Clim. Dynam., 17, 339-359, 2001.
Schneider, S. H.: $\mathrm{CO}_{2}$, climate and society: a brief overview, in: Social Science Research and Climate Change: In Interdisciplinary Appraisal, edited by: Chen, R. S., Boulding, E., and Schneider, S. H., D. Reidel, Boston, MA, USA, 9-15, 1983.

Schreider, S. Y., Smith, D. I., and Jakeman, A. J.: Climate change impacts on urban flooding, Climatic Change, 47, 91-115, 2000.

Schwierz, C., Köllner-Heck, P., Zenklusen Mutter, E., Bresch, D. N., Vidale, P.-L., Wild, M., and Schär, C.: Modelling European winter wind storm losses in current and future climate, Climatic Change, 101, 485-514, doi:10.1007/s10584-009-9712-1, 2010.

Smith, G. H. S., Best, J. L., Ashworth, P. J., Lane, S. N,, Parker, N. O., Lunt, I. A., Thomas, R. E., and Simpson, C. J.: Can we distinguish flood frequency and magnitude in the sedimentological record of rivers?, Geology, 38, 579-582, 2010.

Stainforth, D. A., Aina, T., Christensen, C., Collins, M., Faull, N., Frame, D. J., Kettleborough, J. A., Knight, S., Martin, A., Murphy, J. M., Piani, C., Sexton, D., Smith, L. A., Spicer, R. A., Thorpe, A. J., and Allen, M. R.: Uncertainty in predictions of the climate response to rising levels of greenhouse gases, Nature, 433, 403-406, 2005.

Temme, A. J. A. M. and Veldkamp, A.: Multi-process Late Quaternary landscape evolution modelling reveals lags in climate response over small spatial scales, Earth Surf. Proc. Land., 34, 573-589, 2009.

Temme, A. J. A. M., Baartman, J. E. M., and Schoorl, J. M.: Can uncertain landscape evolution models discriminate between landscape responses to stable and changing future climate? A millennial-scale test, Global Planet. Change, 69, 48-58, 2009.

Tockner, K. and Stanford, J. A.: Riverine flood plains: present state and future trends, Environ. Conserv., 29, 308-330, 2002.

Tucker, G. E. and Bras, R. L.: A stochastic approach to modeling the role of rainfall variability in drainage basin evolution, Water Resour. Res., 36, 1953-1964, 2000.

Tucker, G. E. and Hancock, G. R.: Modelling landscape evolution, Earth Surf. Proc. Land., 35, 28-50, 2010.

Tucker, G. E. and Slingerland, R.: Drainage basin responses to climate change, Water Resour. Res., 33, 2031-2047, 1997.

van Balen, R. T., Busschers, F. S., and Tucker, G. E.: Modeling the response of the Rhineâ Meuse fluvial system to Late Pleistocene climate change, Geomorphology, 114, 440-452, 2010.

Van De Wiel, M. J. and Coulthard, T. J.: Self-organized criticality in river basins: Challenging sedimentary records of environmental change, Geology, 38, 87-90, 2010.

Van De Wiel, M. J., Coulthard, T. J., Macklin, M. G., and Lewin, J.: Embedding reach-scale fluvial dynamics within the CAESAR cellular automaton landscape evolution model, Geomorphology, 90, 283-301, 2007.

Van De Wiel, M. J., Coulthard, T. J., Macklin, M. G., and Lewin, J.: Modelling the response of river systems to environmental change: Progress, problems and prospects for palaeoenvironmental reconstructions, Earth-Sci. Rev., 104, 167-185, 2011.

Verhaar, P. M., Biron, P. M., Ferguson, R. I., and Hoey, T. B.: Numerical modelling of climate change impacts on Saint-Lawrence River tributaries, Earth Surf. Proc. Land., 35, 1184-1198, 2010.

Walling, D. E., Owens, P. N., and Leeks, G. J. L.: Fingerprinting suspended sediment sources in the catchment of the River Ouse, Yorkshire, UK, Hydrol. Process., 13, 955-975, 1999. 
Welsh, K. E., Dearing, J. A., Chiverrell, R. C., and Coulthard, T. J.: Testing a cellular modelling approach to simulating lateHolocene sediment and water transfer from catchment to lake in the French Alps since 1826, Holocene, 19, 785-798, 2009.
Wilcock, P. R. and Crowe, J. C.: Surface-based transport model for mixed-size sediment, J. Hydraul. Eng.-ASCE, 129, 120-128, 2003. 